\title{
Örgüt İçi İletişimin Örgütsel Bağlılığa Etkisi: Türkiye'deki Bankacılık Sektörü Üzerinde Bir Araştırma
}

\author{
Esra (ÜÇOK) ÖKSÜZ* Serhat ULAĞLI**
}

\begin{abstract}
ÖZET
Bu çalışmada Türkiye'deki bankacılık sektöründe algılanan iletişim şeklinin örgütsel bağl1lığa etkisi araştırılmıştır. Araştırmada anket yöntemi kullanılmıştır ve toplam 384 banka çalışanı bu çalışmaya katılmıştır. Sonuçlar göstermiştir ki Türk bankacılık sektöründe iletişim orta derecede "iyi" olarak değerlendirilmektedir. Bu durum çalışanlar tarafindan belirtilen iletişim derecesinin yeterince sağlıklı olmadığını ve bu anlamda gelişime açık olduğunu göstermektedir. Bu anlamda inceleme altındaki bankacılık sektöründe var olan iletişimin toksik iletişime açık bir seviyede olduğu tespit edilmiştir. Araştırma sonuçları örgütsel bağlılık seviyesinin ise orta derecenin altında gerçekleştiğini ortaya koymuştur. Korelasyon analizleri iletişim ve örgütsel bağll1ık arasında pozitif yönlü bir ilişki olduğunu işaret etmiş olsa da regresyon analiz sonucunda bankacılık sektöründeki örgüt içi iletişimin devam bağlılığını ve normatif bağlılığı negatif yönlü etkilediği tespit edilmiştir. Bu durum sektörde var olan örgüt içi iletişimin, sağlıklı bir iletişim olmadığını ve literatürde belirtildiği üzere sağlıklı iletişimin örgütsel bağl1lı̆̆1 pozitif yönlü etkilemesi beklenirken, bu sağlıksız iletişim durumunun örgütsel bağlllık üzerinde negatif bir etki yarattığını ortaya koymaktadır.
\end{abstract}

Araştırma Makalesi

Geliş: 18.01.2021

Kabul: 26.02.2021

Anahtar Kelimeler:

İletişim,

Örgüt İçi İletişim,

Örgütsel Bağlılık,

Bankacıllk Sektörü

\section{Effect Of Organisational Communication On Organisational Commitment: A Study On Banking Industry In Turkey}

ABSTRACT

In this study, the effect of perceived organizational communication on employee commitment in the banking sector in Turkey were investigated. The survey method was used in the study and a total of 384 bank employees participated in this study. The results show that communication in the Turkish banking sector is rated as "moderately good". This result reveals that there is not enough healthy communication among the employees and thus there is a room for the development of communication within the banking sector. This shows that communication within the sector is open for toxic communication. On the other hand, organizational commitment is below the medium level. Although correlation analysis indicated that there is a positive relationship between communication and organisational commitment, regression analysis revealed that intra-organisational communication in the banking sector affected continued commitment and normative commitment negatively. This situation reveals that intraorganisational communication existing in the sector is not an appropriate one and as stated in the literature, it has a negative effect on organizational commitment while the healthy communication should have a positive effect on organisational commitment.

Research Article

Received: 18.01 .2021

Accepted: 26.02.2021

Keywords:

Communication,

Organisational

Communication,

Organisational

Commitment,

Banking Industry

1 “Örgüt İçi İletişimin Çalışan Bağlılığı ve Motivasyona Etkisinin İncelenmesi” başlıklı doktora tezinden üretilmiştir.

${ }^{*}$ Marmara Üniversitesi Sosyal Bilimler Enstitüsü Kișilerarası İletișim A.B.D. Doktora Öğrencisi esraucok@gmail.com, ORCID ID: https://orcid.org/0000-0002-1798-5841

** Prof. Dr. Marmara Üniversitesi İletişim Fakültesi serhat.ulagli@marmara.edu.tr, ORCID ID: https://orcid.org/0000-0001-7565-332X 


\section{GíRiş}

Hem sözel hem sözel olmayan işaretlerin kullanımı ile anlayış geliştirme süreci, "iletişim” olarak bilinmektedir. İletişim süreci iletişimin dolandığı kanallar olan ağlarla işlemektedir. Gerçek mesajdan oluşan iletişim ağlardan alıcıya ulaşmakta; sonuç olarak iletişim etkileri kadar çift yönlü iletişim veya geri bildirim de iletişim sürecini tamamlamaktadır. Bireylerin davranışlarını etki altına almak veya belirli bir amaca ulaşmak için düşünce, duygu, tutum ve davranışların sözlü veya sözsüz olarak iletilmesi sürecini ifade eden iletişim; bir kişinin diğerini etkileyebileceği tüm süreçleri kapsamaktadır (Demirtaş, 2010).

Mesaj gönderen bir kaynak ve alıcı gerektiren bu süreçte bir taraf mesaj gönderdiğinde alıcı taraf bunu dinlemekte ve düşüncelerini karşı tarafa iletmez ise tek yönlü bir iletişim; taraf veya tarafların bir yandan alıcı diğer yandan da kaynak durumunda olması halinde ise çift yönlü bir iletişim söz konusu olmaktadır. Kaynak ve alıcı arasında ortak bir etkileşim ve paylaşım sağlamak, iletişimin ana amacını oluşturmaktadır (Tanrıverdi, Adıgüzel \& Çiftçi, 2010).

Örgüt içi iletişim ise "birden fazla insanın bir amaç etrafında birleşmesini sağlayan ve onların güç birliği yaparak örgüt amaçlarına ulaşma yönünde etkili bir biçimde çalışabilmeleri için, aralarında gerçekleşmesi gereken işbirliğini ve çevresiyle uyumlarını sağlamada önemli bir rolü bulunan, biçimsel ve biçimsel olmayan yapılardaki anlam yükü taşıyan her türlü insan etkinliğinin paylaşılmasıdır” (Ünüvar \& Bilge, 2009: 57 akt: Geçikli, Serçeoğlu \& Üst, 2011: 166).

Örgüt içindeki informel iletişim ağlarında ortaya çıkan, söylenti ve dedikodular ile büyümeye devam eden yıkıcı süreç ise "toksik iletişim” olarak adlandırılmaktadır. Toksik kelimesinin kelime anlamı "solunum yolu ile alınan zehirli bir madde" şeklindedir. Bu anlamda, bu maddeden etkilenmek için maddenin bulunduğu ortamda yer almak yeterli olmaktadır. Toksik iletişim de yalnızca dedikodu ve söylenti gibi sözel ifadeleri değil, bireylerin birbirlerine karşı olan olumsuz ve yıkıcı davranışlarını da içermektedir (Eğinli \& Bitirim, 2008). Örgüt içerisinde sağlıklı olmayan veya toksik yapıda bir iletişimin olması çalışanların motivasyonlarından performanslarına, işlerinden duydukları tatminden iş-aile aile-iş çatışmalarına kadar geniş bir yelpazede etki yaratmaktadır. Bu etkilerin en önemlilerinden biri ise çalışanların örgütsel bağlılıkları üzerinde gerçekleşmektedir. Örgüte bağlılıkları azalan çalışanların ise hem performansları azalmakta hem de işten ayrılma niyetleri yükselmektedir. Bu anlamda örgütün kısır bir döngüye girmesine sebep olan ve sonuçları itibari ile oldukça negatif etkileri bulunan örgüt içi iletişimin incelenmesi ve algılanan iletişim şeklinin örgütsel bağlılığa etkisinin araştırılması oldukça önemlidir. Bu araştırma kapsamında incelenecek olan bu konunun bankacılık sektörü özelinde incelenmesi planlanmıştır. Bankacılık sektörünün ülkemiz ekonomisi açısından oldukça önemli olması ve deneyimli çalışanların sektördeki önemi örgüt içi 
iletişimin örgütsel bağl1lık üzerindeki etkisini bu sektör özelinde araştırmaya iten en önemli sebeplerdendir.

\section{KAVRAMSAL ÇERÇEVE}

\section{İletişim ve Örgüt İçi İletişim}

Tourish \& Hargie (2004) iletişimi mesajlar aracılığıyla kişiler arasında sağlanan sosyal etkileşim olarak görmekteyken; Oliver (1997) iletişim tanımını insanların semboller kullanarak bilgi alışverişi yapması ve bu sembolleri iletirken iletilmek istenenin ana fikir olduğunun bilincinde olması olarak genişletmiştir. İletişim, birbirine bağlı iletişim kanalları aracılığıyla bir kaynak ve bir alıcı arasında bilginin, kaynaktan alıcıya doğru hareket ettiği, bir bilgi değişimi süreci olarak da tanımlanmıştır (Steingrimsdottir, 2011). Dolayısıyla aslında iletişim kurabilmek için her zaman dilin kullanılması zorunluluğu yoktur. Koşullara göre, mimikler, semboller veya giyim tarzı bile iletişim kurmada birer araç görevini üstlenebilmektedir (Kotler \& Keller, 2006). Fakat sözcüklerin iletişimdeki en etkin araç olduğu yadsınamayacak bir gerçektir (Gümüş \& Öksüz, 2009).

Örgütsel düzeyde gerçekleşen örgütsel iletişim, örgütün hedeflerine ulaşmasını sağlamak ve örgüt içi işleyişi sağlıklı bir şekilde yürütmek amacıyla departmanlar arasında ve örgütün çevresi ile ilişkisinde sürekli bilgi ve fikir akışını sağlayan bir toplumsal süreç şeklinde tarif edilmektedir (Güney, 2001).

Örgütsel iletişim iki gruba ikiye ayrılmaktadır; bu gruplar örgüt içi ve örgüt dışı iletişim şeklindedir. Örgüt içi iletişim, örgütün içerisinde çalışan kişiler ile gerçekleşen iletişim türüdür. Örgüt dışı iletişim ise örgütün dış çevresi ile gerçekleştirmekte olduğu iletişime denilmektedir (Bovee \& Thill, 2010). Örgütsel gelişim, hedeflerin tanımlanması ve çalışan ilişkileri gibi unsurlar örgüt içi iletişimin konularının arasında görülmektedir (Cheney \& Christensen, 2001). Bu anlamda örgütlerin başarıya ulaşmaları ve rakiplerine karşı rekabet avantajı sağlamalarında etkili bir iletişimin rolünün büyük olduğu belirtilmektedir (Kalla, 2005). Buna göre örgüt içi iletişim; örgütün stratejik ve işlevsel planlama sürecinde var olan tüm rutin ve gündelik faaliyetlerin düzenlenmesi ve koordine edilmesi süreçlerinde farklı uzmanlık ve seviyelerdeki bireyler ve gruplar arasında gerçekleşen etkileşim şeklinde tanımlanabilmektedir (Aldehayyat, 2011).

Örgütte çalışanlar arasındaki iletişim birçok çeşitli yol ve kanal aracılığı ile gerçekleşebilmektedir. Bu kanallarda iletişim üç yönde akmaktadır; bunlar dikey, yatay ve çapraz olarak ayrılmıştır (Ünüvar \& Bilge, 2009).

Dikey İletişim: Yöneticiler ve astlarının birbirleriyle gerçekleştirdikleri iletişime dikey iletişim adı verilmektedir. Bu iletişim şekli yöneticiden asta (aşağı) olabileceği gibi asttan yöneticiye (yukarı) da olabilmektedir. Yöneticiden asta gerçekleşen iletişim çalışanlara bilgi verme ve performanslarını 
değerlendirme, örgüt hedeflerinin astlara aktarılması gibi sebeplerden gerçekleşebileceği gibi alt kadrolarda yaşanan durumların yöneticilere aktarılması ise asttan yöneticiye olan iletişimin temel sebebini oluşturmaktadır (Geçikli, Serçeoğlu \& Üst, 2011).

Yatay İletişim: Aynı seviyede olan çalışanların birbirleri ile olan iletişim ise yatay iletişim olarak isimlendirilmektedir. Takım çalışmalarında daha çok ortaya çıkan bu iletişim şekli bilgi vermekten ziyade çalışanların birbirlerine destek olması, birlikte çalışmanın, bir başka deyişle koordinasyonun etkinleştirilmesi gibi sebeplerle ortaya çıkmakta ve gerçekleşmektedir (Geçikli, Serçeoğlu \& Üst, 2011).

Çapraz İletişim: Farklı işlevsel örgüt birimlerinde çalışan yöneticiler ve astlar arasında ortaya çıkan ve temel sebebi bilgi paylaşımı olan iletişim ise çapraz iletişim olarak isimlendirilmektedir. Bu iletişim türü daha çok farklı birimlerin birbirlerinin hedeflerini ve beklentilerini anlamak adına kullanılmakta olup örgütün bütün halinde performansının geliştirilmesi hedeflenen iletişim yöntemidir (Geçikli, Serçeoğlu \& Üst, 2011).

$\mathrm{Bu}$ iletişim şekillerinin dişında iletişim yöntemleri de bulunmaktadır. Bunlar formel ve informel iletişim şekilleridir. Formel iletişim örgüt içinde belirli kalıplara göre şekillenen iletişim şekli iken informel iletişim günlük olayların akışına göre ortaya çıkabilen resmi olmayan iletişim şeklidir. Resmi olmayan iletişim şekilleri örgütlerde ortaya çıkan iletişim sorunlarının da başında gelmektedir. Örgüt içindeki informel iletişim ağlarında ortaya çıkan, söylenti ve dedikodular ile büyümeye devam eden yıkıcı süreç ise "toksik iletişim” olarak adlandırılmaktadır. Bektaş ve Erkal'a (2015) göre tüm örgütler az ya da çok toksik iletişim özellikleri göstermektedirler. Bu anlamda işletmelerde iletişim yeterince iyi değilse toksik iletişim yerleşmeye başlamakta ve hızla yayılmaktadır (Bektaş \& Erkal, 2015). Bu anlamda araştırmanın bu bölümünde toksik iletişim kavramına değinilecektir.

\section{Örgütlerde Toksik İletişim}

Toksik iletişim, örgütteki çalışanların işten daha fazla kişilere odaklanarak, onlara zarar vermeyi amaçlayan söylem ve tavırların bütününü ifade etmektedir. Toksik iletişim, sözel anlamda dedikodu ve söylentiler ile karakterize edilirken, sözsüz iletişimde de sağlıksız davranış ve tepkiler ile karakterize edilmektedir (Eğinli \& Bitirim, 2008).

Allport \& Postman (1947) tarafından toksik iletişimi meydana getiren dedikodu ve söylentiler iki varsayım doğrultusunda ortaya çıkmaktadır.

$\mathrm{Bu}$ varsayımlardan birincisi, insanlar olayların meydana gelmesinin gerçek nedenlerini merak etmektedirler; ikincisi ise bir olayın içerisinde belirsizlikler varsa bu olayı başka şekillerde anlatarak 
ona anlam yüklemeye çalışmaktadırlar (Solmaz, 2004). Rosnow'a (1991) göre, dedikodu ve söylentilerin yayılmasının altında dört önemli etmen yer almaktadır.

Bu etmenler şu şekildedir: "dinleyiciye konu ile ilgili bir sonuç taşımalı, kişisel kaygıyı çoğaltmalı, belirsizliği (iki anlamlılık) genelleştirmeli ve biraz güvenilirlik taşımalıdır” (Guerin \& Yoshihiko, 2006). Aşağıdaki şekilde bir örgüt içerisinde meydana gelen negatif davranışlar ve bunlara yönelik iletişim biçimleri yer almaktadır:

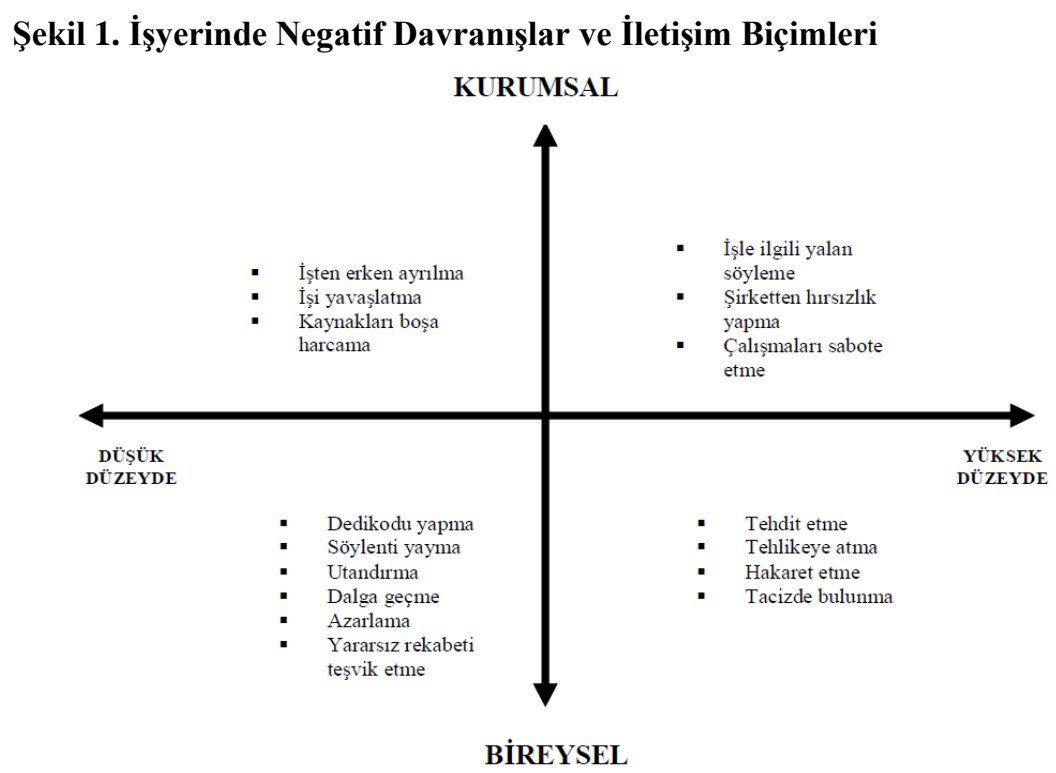

Kaynak: Appelbaum, Iaconi \& Matousek (2007)

Örgütlerde toksik iletişim, çeşitli kanallardan gerçekleşmektedir. Bunlar aşağıda detaylı açıklanmaktadır:

İnformel Gruplar: Grup kavramı, ortak ilke ve davranışları benimseyen, ortak bir amacı paylaşan ve bu amaç ekseninde iletişim kuran iki veya daha fazla kişinin bir araya gelerek oluşturmuş olduğu sosyal bir olguyu tarif etmektedir. Bu sosyal olgu içerisinde, kişiler aynı zamanda karşılıklı olarak birbirlerini etkilemektedirler (Koçel, 2018).

Yöneticilerin İnformel Ziyaretleri: İlk olarak 1970’li yıllarda Hewlett-Packard bilgisayar şirketinde görev yapmakta olan Bill Hewlett ve Bill Packard isimli yöneticiler tarafından geliştirilen "yöneticilerin informel ziyaretleri (Management By Walking Around)" kavramı yöneticilerin işle alakalı konularda direkt olarak çalışanlarının arasına karıştığı bir yaklaşımdır. İnformel ziyaretler, katı ve uzaktan yönetim anlayışının tam tersi olarak ortaya çıkmıştır. Bu yaklaşımda yöneticiler, informel ziyaretler sırasında zamanlarının büyük bir kısmını, çalışanları ile iletişimlerini arttırmak ve etkileşimde bulunmak için harcamaktadırlar (Bektaş \& Erdem, 2015). Ancak bu informel ziyaretler sırasında olumsuz durumlar ile de sıklıkla karşılaşılmaktadır. 
Örneğin informel ziyaretler aynı zamanda informel hitapların ve günlük konuşma dilinin sıklıkla kullanıldığı durumları ortaya çıkarmaktadır. Bu tarz durumlarda hem yöneticiler hem de çalışanlar bu ziyaretlerden olumsuz etkilenmekte ve motivasyon kaybına uğramaktadır. Benzer şekilde bu ziyaretler sırasında ortaya çıkan beklentiler, istekler, cevaplanamayan sorular gibi durumlar da sağlıksız, bir başka deyişle toksik iletişimi ortaya çıkartmakta ve bu durum özellikle çalışanlar arasında motivasyon düşüklüğüne yol açmaktadır (Bektaş \& Erdem, 2015).

Kurum İçi Sohbetler: Çoğunlukla bir konuşma hazırlığı gerektirmeyen ve anlık gelişen günlük konuşmalar şeklinde olmaktadır. Bu sohbetler sayesinde, bireyler yakınlaşmakta ve birbirlerini daha iyi anlayabilmektedirler (Moutoux \& Porte, 1979). Bu tarz sohbetler genellikle kurum içinde “dedikodu" yaratmakta ve yine genellikle yanlış veya hatalı bilgilerin yayılmasını tetiklemektedir. Yanlış, eksik, hatalı ve benzeri bilgiler kurum içinde oluşması beklenilen sağlıklı iletişimin en temel düşmanlarından biridir ve çalışanların motivasyonları ve bağlılıkları üzerinde oldukça fazla negatif etkiye sahiptir (Bektaş \& Erdem, 2015).

Laf Taşıyıcılar: Örgüt içerisinde çalışan bireyler duydukları informel bilgileri düzenli bir şekilde bir yerden bir yere aktarmaktadırlar. Bunu bazen özellikle isteyerek bazen de farkında olmadan istemeden yapmaktadırlar. Bu tarz kişiler örgüt içerisinde "laf taşıyıcı" şeklinde adlandırılmaktadırlar. Laf taşıyıcıların, informel iletişimde kilit rolleri bulunmaktadır. Bu tarz kişiler, bir yerden başka bir yere bilgi aktarımı yaparken istemsiz olarak diğer örgüt çalışanları da bu sürece dahil olmaktadırlar (Bektaş \& Erdem, 2015).

Dedikodu ve Söylenti Ağı: Örgüt içerisinde informel iletişim kanalları arasında yer almaktadır. Bunların üç temel özellikleri bulunmaktadır: birdenbire ortaya çıkmaları, örgüt içerisinde üst kademe yöneticiler tarafından kontrol edilmelerinin zorluğu ve çalışanların kendi çıkarlarına yönelik ortaya çıkmaları (Certo \& Certo, 2006).

Şakalar: Güldürmek ve eğlendirmek amacıyla karşıdaki kişiyi kırmadan yapılan davranışlar ve söylemler "şaka" olarak nitelendirilmektedir. Örgüt içerisinde şakalar, kelime oyunları ile yapılan zararsız şakalar, acımasız şakalar ve cinsel içerikli şakalar olmak üzere üç farklı şekilde olabilmektedir. Bazı durumlarda şakalar, örgüt içerisinde yöneticilerin ve çalışanların aslında birbirlerine söylemek istedikleri fakat söylemedikleri ifadeleri, birbirlerine daha rahat aktarmalarına uygun bir atmosfer sağlayabilmektedir.

Örneğin aslında çok ciddi bir mesaj, şaka yoluyla yumuşatılarak daha rahat karşı tarafa iletilebilmektedir (Bektaş \& Erdem, 2015). Ancak bu gibi durumlar çalışanlar arasında tedirginlik yaratma noktasında oldukça etkilidirler. Çalışanlar bu, özellikle yöneticileri tarafından yapılan şakaları 
yanlış anlayabilmekte ve böylece işe karşı geliştirdikleri motivasyonları kaybedebilmektedirler. Yukarıda da belirtildiği üzere özellikle informel ziyaretler şakaların yaygınlıkla gerçekleşebildiği ortamları yaratmaktadır. Bu anlamda özellikle yöneticiler yapacakları informel ziyaretlerde tutum ve davranışlarına gerektiğinden fazla özen göstermelidirler (Bektaş \& Erdem, 2015).

İnformel Sanal İletişim: Özellikle 1990'lı yılların başından itibaren, yaşanan teknolojik gelişmelerin bir sonucu olarak sanal dünya ve bu sanal dünyadaki iletişim ağları örgütlerin içerisinde de önemli bir rol oynamaya başlamıştır. Sanal dünya örgütlerin içerisine girerek, yeni iletişim kanallarının çok daha hızlı bir şekilde yayılmasına olanak sağlamıştır. Özellikle internet ağlarının varlığı ile birlikte, hem işlerin yapılması süresi hızlanmış, hem de çalışanların beklentilerinde artışlar olmuştur. İnformel sanal iletişim, örgüt çalışanlarının birbirleri ile yüze yüze kuramadıkları veya kurmak istemedikleri iletişim durumunda devreye girmektedir. Ancak, örgüt içerisinde dedikodu ve söylentilerin daha rahat söylenip daha hızlı yayılması gibi olumsuz durumlara da neden olabilmektedir (Eğinli \& Bitirim, 2008).

Sosyal Etkinlikler: Kişilerin sosyal gereksinimlerini karşılamak, eğlenmek, karşılıklı bilgi alışverişinde bulunmak amaçları ile düzenlenen faaliyetlerin toplamı sosyal etkinlik olarak adlandırılmaktadır. Örgüt içerisinde düzenlenen sosyal etkinliklerin, iyi yönetildikleri takdirde, örgüte oldukça olumlu katkılarının olduğu ifade edilmektedir. Sosyal etkinlikler çalışanların motivasyon seviyelerini yükseltebilmekte, bu sayede de işe doyumlarını arttırabilmektedir. Fakat tüm bunların aksine iyi yönetilemeyen sosyal etkinlikler, örgüt içerisinde yalan ve yanlış bilgilerin yayıldı̆̆ bir ortam haline dönüşebilmektedir (Bektaş \& Erdem, 2015).

\section{Örgütsel Bağlılık Kavramı}

Meyer \& Allen (1991) örgütsel bağl1lık kavramını, "bir çalışanın örgüt ile olan ilişkisini belirleyen ve örgütün üyesi olarak kalma ya da örgütten ayrılma kararını etkileyen psikolojik bir durum" olarak ifade etmektedirler. Porter, Steer, Mowday \& Boulian'in (1974) örgütsel bağlılığa ilişkin tanımında belirtilmiş olan yönlerin ise literatürdeki yeri önemlidir.

Bu yönler; çalışanların örgüt üyesi olarak kalmaya dair duydukları kuvvetli istek, örgüt adına daha çok çaba sarf etme isteği ve örgütsel değerlere güçlü bir inanç duyulup kabul edilmesidir (Yousef, 2003). Örgütsel bağlılığın; davranışsal, tutumsal ve çoklu bağlılık olmak üzere üç temel sınıflandırılması olduğu bu konuda yapılan araştırmalar ve geliştirilen modeller neticesinde ortaya konulmuştur. Örgütten çok çalışanın kendi davranışları ile ilgili olan davranışsal bağlılık üzerinde özellikle sosyal psikologlar tarafından incelemeler yapılmıştır. Çalışanların belirli bir davranışta bulunmasının ardından, o davranışı devam ettirme eğilimi içinde olmalarını ifade etmektedir. Akabinde gösterilen davranışla uyumlu tutumların gösterildiği bir gerçektir. Tutumsal bağl1lık ise örgütsel davranış 
araştırmacılarınca ele alınmış ve çalışanların davranışlarına dair niyetleri ön plana alınmıştır (Gül, 2002). Söz konusu yaklaşımda; “örgütte kalma arzusu, örgütün iyiliği için daha fazla çaba gösterme istekliliği ya da örgütün amaçları ile özdeşleşme gibi tutumlar” örgütsel bağlılıkla açıklanmaktadır. Akademik çevreler, davranışsal yaklaşım literatüründe Meyer \& Allen'in (1991) önerdiği ve kavramsallaştırdığı üç boyutlu örgütsel bağlılık modeline büyük ilgi göstermişlerdir. Araştırmalar neticesinde bu model farklı kültür ve sektörlerden pek çok ampirik destek almıştır.

\section{Örgütsel Bağlılığın Seviyeleri ve Sınıflandırması}

Bireyin bireysel örgütsel bağlılık gelişimine bağlı olarak farklı örgütsel bağlılık seviyeleri bulunmaktadır. Aşağıdaki şekil, örgütsel bağlılığın arttığı ve azaldığ1 durumlardaki bağl1lık seviyelerini göstermektedir. Çalışanın bağlılık seviyesi düşük seviyeden orta seviyeye gelebilmekte ve buradan da daha yüksek bir bağlılık seviyesine ulaşılabilmektedir (Reichers, 1985).

\section{Şekil 2. Örgütsel Bağlılık Gelişim Seviyeleri}
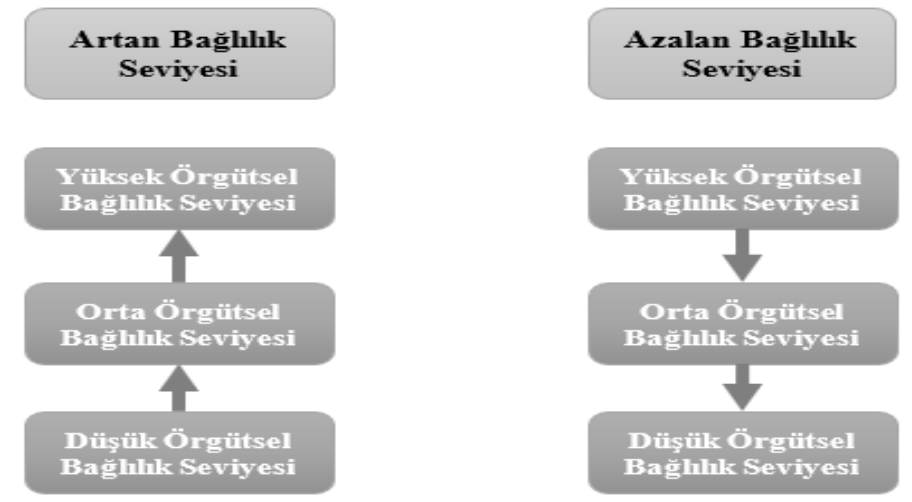

Kaynak: Reichers (1985)

Aşağıda örgütsel bağlılık seviyeleri açıklanmaktadır:

Yüksek Örgütsel Bağl1lık Seviyesi: Yüksek örgütsel bağlılık seviyesinin özellikleri, örgütün değerlerini güçlü bir şekilde kabul etme ve örgüt içinde kalmak için çaba sarf etme konusunda istekli olmadır (Reichers, 1985). Miller (2003) “yüksek örgütsel bağlılığın bireyin kendisini çalıştığı örgüt ile özdeşleştirmesi anlamına geldiğini" ifade etmektedir. "Kalma isteği” bu seviyedeki davranış eğilimlerinin, bireylerin istedikleri için örgütte kalmalarını ifade eden, bağlılığın duygusal boyutu ile yakından ilişkilidir.

Orta Örgütsel Bağlılık Seviyesi: Orta örgütsel bağlılık seviyesinin özellikleri, örgütün hedeflerini ve değerlerini makul bir şekilde kabul etme ve örgüt içinde kalmak için çaba sarf etme konusunda istekli olmadır (Reichers, 1985). Bu seviye kısmi bir bağlılık anlamına gelen makul ya da ortalama bir bağl1lık olarak değerlendirilebilmektedir. Kalmaya istekli olma, bağlılığın normatif boyutu ile ilişkili moral bir 
bağlılık özelliğidir (Meyer \& Allen, 1997). Bireyler kalmaları gerektiği için örgüt içinde kalmaktadırlar.

Düşük Örgütsel Bağl1lık Seviyesi: Düşük örgütsel bağlılık seviyesinin özellikleri, örgütün hedeflerini ve değerlerini kabul etmeme ve örgüt içinde kalmak için çaba sarf etme konusunda istekli olmamadır (Reichers, 1985). Bu seviyede bulunan çalışan örgüt konusunda hayal kırıklığına uğramıştır. Böyle bir çalışan örgütte kalabilir, çünkü devamlılık boyutunun özelliği olarak kalma ihtiyacı içindedir (Meyer \& Allen, 1997). Bu tür çalışanlar firsat bulduklarında örgütten ayrılmaktadırlar.

\section{Örgütsel Bağlılığa Etki Eden Faktörler}

Örgütsel bağl1lığı etkileyen çeşitli faktörler bulunmaktadır. Bu faktörler işle ilgili faktörler, iş imkânları, kişisel özellikler, olumlu ilişkiler, örgüt yapısı ve yönetim tarzıdır:

İşle İlgili Faktörler: Bireysel seviyede örgütsel bağlılık işle ilgili önemli bir çıktıdır. Bu çıktının fire, devamsızlık, iş için gösterilen çaba, iş rolü ve performans gibi diğer işle ilgili çıktılar üzerinde etkisi olabilmektedir (Randall, 1990). Belirsiz olan bir iş rolü örgüte olan bağlılık eksikliğine neden olabilmektedir. Benzer şekilde terfi imkânları da örgütsel bağlılığı artırabilmekte ya da azaltabilmektedir.

Bağl1lık üzerinde etkili olabilecek diğer iş faktörleri ise sorumluluk ve özerklik seviyeleridir. Bir iş için sorumluluk ve özerklik seviyesi yükseldikçe işin daha az tekrar içerdiğini ve daha ilginç olduğunu, buna bağlı olarak işi yapan kişinin daha yüksek bağl1lık gösterdiği belirtilmektedir (Meyer \& Allen, 1997).

İş İmkânları: İş imkânlarının varlığı örgütsel bağlılı̆̆ı etkileyebilmektedir. Başka bir iş bulmak için şanslı olduğu konusunda güçlü bir sezgisi olan bireyler, arzu edilir diğer alternatifler üzerinde kafa yorarken örgüte daha az bağlılık gösterebilmektedirler. Başka istihdam imkânlarının olmadığ durumlarda ise, yüksek örgütsel bağlılık seviyesine doğru bir eğilim bulunmaktadır. Sonuç olarak, örgüt üyeliği çalışanların sürekli olarak kalmanın ve gitmenin risklerini hesapladıkları devamlılık bağl1lığı temellidir (Meyer \& Allen, 1997).

Kişisel Özellikler: Örgütsel bağlılık, aynı zamanda çalışanın yaşı, hizmet süresi ve cinsiyeti gibi kişisel özelliklerinden de etkilenebilmektedir. Kadrolu ya da kıdemli olan yaşlı çalışanlar ile kendi iş performanslarından memnun olan çalışanların, diğerlerine kıyasla daha yüksek örgütsel bağlılık seviyeleri göstermeye eğimli oldukları belirtilmektedir. Diğer bir ifade ile, yaşlı insanların diğer yaş gruplarına göre örgüte daha fazla bağlılık gösterdiği gözlemlenmektedir. 
Örgütsel bağl1lığı etkileyebilen diğer bir kişisel özellik de cinsiyettir (Meyer \& Allen, 1997). Ancak, bağlılık konusundaki cinsiyet farklılıklarının cinsiyet ile ilişkilendirilen farklı iş özelliklerinden ve tecrübelerinden kaynaklandığı da iddia edilmektedir.

İş Ortamı: İş ortamı da örgütsel bağlılığı etkileyen diğer faktörlerden biridir. Bir şirketin ortağı olmak, örgütsel bağlılığı genellikle olumlu yönde etkileyebilen iş ortamı koşullarından bir tanesidir. Hangi tür olursa olsun sahiplik duygusu, çalışana önemli olduğunu ve karar verme sürecinin bir parçası olduğunu hissettirmektedir. Bu sahiplik kavramının içinde iş uygulamalarında meydana gelecek yeni gelişmeler ve değişiklikler hakkında verilecek kararların bir parçası olmak vardır ve bu nedenle bir aidiyet duygusu yaratmaktadır. Subramaniam \& Mia (2001) tarafından yapılan bir çalışmada bütçe kararlarının verilmesi sürecine katılan yöneticilerin yüksek örgütsel bağlılık seviyesine sahip olma eğiliminde oldukları görülmektedir.

İş ortamında örgütsel bağl1lı̆ğ etkileyebilen diğer bir faktör de işe alma, seçim, performans değerlendirme, terfi ve yönetim tarzı ile ilgili iş uygulamalarıdır (Meyer \& Allen, 1997). Metcalfe \& Dick (2001) çalışmalarında, polis memurlarında gözlenen düşük örgütsel bağlılık seviyesinin, uygun olmayan seçim ve terfilerden kaynaklanan ve astların örgütsel bağlılığı üzerinde olumsuz etkileri olan, süregelen yönetim tarzı ve davranışı ile ilgili olduğu sonucuna varmışlardır.

Olumlu İlişkiler: Bir iş yeri ortamı olarak örgüt, yönetsel ilişki de dâhil olmak üzere, iş ilişkilerinden oluşmaktadır. Randall’a (1990) göre, “yönetsel ilişki örgütsel bağlılığı olumlu ya da olumsuz yönde etkileyebilir". Olumlu bir yönetsel ilişki örgüt içinde performans yönetimi gibi işle ilgili uygulamaların yapılma şekline bağlıdır (Randall, 1990). Bireyler uygulamalar içinde yönetsel ilişkinin adil bir biçimde kurulduğunu gördüklerinde örgüte daha fazla bağlanma eğilimi göstermektedirler (Benkhoff, 1997).

İş yerinde var olan takımlar ya da gruplar gibi ilişkiler de örgütsel bağlılığı etkileyebilmektedir. Benkhoff (1997) çalışan bağlılığının ve örgüte sevginin, örgütün sosyal atmosferini ve amaç duygusunu geliştirmek için harcanacak çabalar ile artırılabileceğini belirtmektedir. Aslında, iş ilişkileri içinde örgüt ve bireyler arasında karşılıklı olarak saygı olduğunda, bireyler örgütsel bağlılık geliştirebilmektedirler.

Örgüt Yapısı: Örgüt yapısı, örgütsel bağlılık içinde önemli bir rol oynamaktadır. Bürokratik yapıların örgütsel bağlılık üzerinde olumsuz bir etkisi vardır. Zeffanne (1994) "bürokratik bariyerleri kaldırmanın ve daha esnek bir yapı kurmanın, örgüte hem sadakat hem de sevgi duymak anlamındaki çalışan bağlılığını büyük ihtimalle artıracağına” işaret etmektedir. Yönetim de çalışanlara daha fazla yönlendirme ve etki sağlayarak bağlılık seviyesini artırabilmektedir (Storey, 2007). 
Yönetim Tarzı: Zeffanne (1994) tarafından, çalışan bağlılığı, morali, sadakati ve sevgisi sorusunun cevabının sadece güdüleyiciler sunarak bulunamayacağı, aynı zamanda bağlama ve çağdaş çalışan arzularına uygun olmayan yönetim tarzları gibi çalışanların şevkini kıran etmenlerin de ortamdan kaldırılması gerektiği ifade edilmektedir. Çalışan katılımını teşvik eden bir yönetim tarzı ile çalışanın yetki alma arzusu tatmin edilebilmekte ve çalışanlardan örgüt amaçlarına bağlılık göstermesi istenebilmektedir. Gaertner (1999), daha esnek ve katılımcı yönetim tarzlarının örgütsel bağlılığı olumlu yönde ve güçlü biçimde geliştirdiğini iddia etmektedir. Örgütler, yönetim stratejilerinin amacını çalışanların uyumundan ziyade bağlılığını iyileştirecek şekilde belirlemelidirler (Williams \& Anderson, 1991).

Tüm bu bahsi geçen faktörlerin hepsinde önemli rolü olan bir değişken vardır ki o da örgüt içinde gerçekleşen veya var olan iletişimdir. İletişim her şeyin temeli olduğu gibi örgütsel bağlılığa etki eden faktörlerin hepsinde de etkin rol oynamaktadır (Bektaşoğlu \& Şengün, 2020). Bu anlamda bu araştırmanın hipotezi (H1) “örgüt içi iletişimin örgütsel bağl1lığa etkisi vardır” şeklinde belirlenmiştir.

\section{YÖNTEM}

$\mathrm{Bu}$ araştırmanın amacı örgüt içi iletişimin örgütsel bağlılığa etkisi olarak belirlenmiştir. Araştırma Türkiye'deki bankacılık sektörü üzerinde yapılmıştır. Bu noktadan hareketle; Türkiye'deki bankacılık sektöründe örgüt içi iletişim hangi seviyede sağlıklı olarak algılanmaktadır?, Türkiye'deki bankacılık sektöründe örgütsel bağl1lık seviyesi nedir?, Türkiye'deki bankacılık sektöründe algılanan iletişim şeklinin örgütsel bağlılığa etkisi var mıdır? soruları araştırma kapsamında cevap aranacak sorulardır.

Araştırmada anket yöntemi kullanılmıştır. Anket oluştururken iki farklı ölçekten yararlanılmıştır: örgüt içi iletişim ölçeği ve örgütsel bağlılık ölçeği.

Araştırmada kullanılan örgüt içi iletişim ölçeği, Halis'in (2000) çalışmasından uyarlanmıştır. Ölçekte toplam 36 adet madde bulunmakta olup, bu maddelerin derecelendirmesi de 5'li Likert sistemine göre hazırlanmıştır. "Kesinlikle katılmıyorum (1), katılmıyorum (2), kararsızım (3), katılıyorum (4) ve kesinlikle katılıyorum (5)" seçeneklerinden oluşmaktadır.

Halis'in (2000) çalışmasında örgüt içi iletişim ölçeğine ilişkin toplam 6 adet alt faktör bulunmaktadır. Ölçek maddelerinin faktörlere göre dağılımı ise aşağıda yer almaktadır:

1. Kişisel başarı duygusu yaratan iletişim: $1,2,3,4,5,6,7,8,9,10$

2. İletişimin işini tatmin edici bulma yönü: $11,12,13,14,15,16,17$

3. Açık iletişim ve iş güvenliği: 18, 19, 20, 21, 22

4. Üstlerin açık olmayan davranışları ve denetim algısı: 23, 24, 25, 26, 27 
5. İletişimin gelişme firsatlarına katkısı: 28, 29, 30, 31, 32

6. İşyeri ilişkilerindeki belirsizlik: 33, 34, 35, 36

$\mathrm{Bu}$ araştırmada yapılan faktör analizi sonucunda da, meydana gelen alt boyutların Halis (2000) tarafından oluşturulan orijinal anket formundaki ile bire bir uyumlu olduğu belirlenmiştir. Bu sonuç, ölçeğin yapı geçerliliğine sahip olduğunu göstermektedir. Yapılan güvenilirlik analizi sonucunda, ölçeğin güvenilirlik katsayısı (Cronbach Alpha değeri) ise 0.962 olarak bulunmuştur, bu değer de ölçeğin çok yüksek seviyede güvenilir olduğu anlamını taşımaktadır.

Örgütsel Bağlılık Ölçeği: Meyer \& Allen (2004) tarafından geliştirilen “Üç Boyutlu Örgütsel Bağlılık Ölçeği” kullanılmıştır. Ölçekte toplam 17 soru bulunmakta olup, 5'li Likert skalası kullanılmıştır. Cevaplar "kesinlikle katılmıyorum (1), katılmıyorum (2), kararsızım (3), katılıyorum (4) ve kesinlikle kat1lıyorum (5)" şeklinde düzenlenmiştir. Ölçek 3 alt boyuttan meydana gelmektedir, bu alt boyutlar “duygusal bağlılık, devam bağlılı̆̆1 ve normatif bağlılık” şeklindedir. Ölçekte yer alan 1., 2., 3., 4., 5. ve 6. maddeler duygusal bağlılık boyutunu; 7., 8., 9., 10., 11. ve 12. maddeler devam bağl1lı̆g boyutunu; 13., 14., 15., 16. ve 17. maddeler ise normatif bağlılık boyutunu oluşturmaktadır. Verilerin çözümlenmesinde bu maddelerin aritmetik ortalaması alınmaktadır.

$\mathrm{Bu}$ araştırmada yapılan faktör analizi sonucunda da, meydana gelen alt boyutların Meyer \& Allen (2004) tarafından oluşturulan orijinal anket formundaki ile bire bir uyumlu olduğu belirlenmiştir. Bu sonuç, ölçeğin yapı geçerliliğine sahip olduğunu göstermektedir.

Araştırmada ölçeğin güvenilirlik katsayısı (Cronbach Alpha değeri) ise 0.897 olarak bulunmuştur, bu değer de ölçeğin yüksek seviyede güvenilir olduğu anlamına gelmektedir.

Araştırmanın evreni Türkiye'de bankacılık sektöründe çalışan tüm çalışanları kapsamaktadır. Mart 2020 itibari ile Türk bankacılık sektöründe toplamda 54 banka bulunmaktadır. Bu bankaların 34'ü mevduat bankaları, 14'ü kalkınma ve yatırım bankaları, 6'sı da katılım bankalarından oluşmaktadır (Türkiye Bankalar Birliği, 2020). Bu bankalarda yine Mart 2020 itibariyle çalışan sayısı 188.164 olarak gerçekleşmiştir. \%99 güvenirlik ve \%5 hata payı ile ortaya çıkan örneklem sayısı 663 olmuştur. E-mail aracılığg ile anketler çalışanlara gönderilmiş ancak toplamda 384 geri dönüş sağlanmıştır ve bu anketlerin tamamı analiz için kullanılmıştır.

Araştırmanın analizinde ilk önce betimsel istatistiklere yer verilmiş olup mean-median analizleri yardımıyla Türk bankacılık sektöründeki iletişimin sağlıklı olup olmadığı ve örgütsel bağlılık seviyeleri belirlenmiştir. Bunu takiben korelasyon analizleri ve regresyon analizleri yapılarak algılanan iletişim şekli ve örgütsel bağlılık arasındaki ilişki ve etkileşimler tespit edilmiştir. Araştırmada analiz software'i olarak SPSS 25.0 kullanılmıştır. 


\section{BULGULAR}

\section{Katılımcı Profili}

Çalışmada öncelikle araştırmaya katılan banka çalışanlarının demografik özellikleri, iletişim ve örgütsel bağlılık düzeylerine ilişkin tanımlayıcı istatistiklere yer verilmiştir. Daha sonra ise çalışanların iletişim ile örgütsel bağlılık düzeyleri arasındaki ilişkinin incelenmesi adına korelasyon analizi ve basit doğrusal regresyon analizleri uygulanmıştır.

Tablo 1'de araştırmaya katılan bankacılık sektöründe çalışan katılımcıların demografik özelliklerine ve çalıştıkları kurumdaki departman ve pozisyonlarına ilişkin bilgiler yer almaktadır.

Tablo 1. Katılımcı Profili

\begin{tabular}{|c|c|c|c|c|c|c|c|}
\hline \multicolumn{2}{|c|}{ Demografik Özellikler } & \multirow{2}{*}{$\frac{\text { Sayı }}{273}$} & \multirow{2}{*}{$\frac{\%}{\% 71}$} & \multicolumn{2}{|c|}{ Demografik Özellikler } & \multirow{2}{*}{$\frac{\text { Sayı }}{24}$} & \multirow{2}{*}{$\frac{\%}{\% 6}$} \\
\hline Cinsiyet & Kadın & & & \multirow{8}{*}{$\begin{array}{l}\text { Kurumdaki } \\
\text { pozisyon }\end{array}$} & Vezne & & \\
\hline & Erkek & 111 & $\% 29$ & & $\begin{array}{l}\text { Müşteri hizmetleri } \\
\text { temsilcisi }\end{array}$ & 15 & $\% 4$ \\
\hline \multirow[t]{4}{*}{ Yaş } & $20-29$ & 48 & $\% 13$ & & Uzman & 102 & $\% 27$ \\
\hline & $30-39$ & 156 & $\% 41$ & & Uzman yardımcis1 & 30 & $\% 8$ \\
\hline & $40-49$ & 171 & $\% 44$ & & Birim yöneticisi & 51 & $\% 13$ \\
\hline & $50+$ & 9 & $\% 2$ & & Müdür & 111 & $\% 29$ \\
\hline \multirow{2}{*}{$\begin{array}{l}\text { Medeni } \\
\text { durum }\end{array}$} & Evli & 249 & $\% 65$ & & Müdür yardımcısı & 9 & $\% 2$ \\
\hline & Bekar & 135 & $\% 35$ & & Grup yöneticisi & 42 & $\% 11$ \\
\hline \multirow[t]{3}{*}{$\begin{array}{l}\text { Eğitim } \\
\text { durumu }\end{array}$} & $\begin{array}{l}\text { Üniversite } \\
\text { mezunu }\end{array}$ & 261 & $\% 68$ & \multirow[t]{6}{*}{$\begin{array}{l}\text { Çalışılan } \\
\text { departman }\end{array}$} & Satış-pazarlama & 162 & $\% 42$ \\
\hline & $\begin{array}{l}\text { Yüksek lisans } \\
\text { mezunu }\end{array}$ & 111 & $\% 29$ & & Muhasebe-finans & 51 & $\% 13$ \\
\hline & $\begin{array}{l}\text { Doktora } \\
\text { mezunu }\end{array}$ & 12 & $\% 3$ & & İnsan kaynakları & 59 & $\% 18$ \\
\hline \multirow{3}{*}{$\begin{array}{l}\text { Kurum } \\
\text { türü }\end{array}$} & Yerel & 228 & $\% 59$ & & Denetim-kontrol & 12 & $\% 3$ \\
\hline & Global & 87 & $\% 23$ & & Özel bankacilik & 33 & $\% 9$ \\
\hline & $\begin{array}{l}\text { Yabanc1 } \\
\text { ortakl1 }\end{array}$ & 69 & $\% 18$ & & Üst yönetim & 57 & $\% 15$ \\
\hline
\end{tabular}

Verilerin analizi sonucunda, katılımcıların çoğunluğunun kadınlardan (\%71) oluştuğu ve yaş aralığının da en çok 30 ile 49 yaş arasında olduğu anlaşılmaktadır. Katılımcıların \%65'i evli iken, eğitim durumuna bakıldığında çoğunluğunun (\%68) üniversite mezunu oldukları görülmektedir. Çalışılan kurum türü değerlendirmesinde, katılımcıların \%59'unun yerel bir kurumda, \%23'ünün global bir kurumda ve \%18'inin de yabancı ortaklı bir kurumda çalıştıkları görülmektedir. Katılımcıların çalıştıkları departman bazında yapılan inceleme doğrultusunda ise, çoğunluğunun (\%42'sinin) satışpazarlama departmanında çalıştıkları anlaşılmaktadır. Kurumdaki pozisyon değerlendirmesinde de katılımcıların çoğunluğunun müdür (\%29) ve uzman (\%27) pozisyonlarında çalıştıkları görülmektedir. 


\section{İletişim ve Örgütsel Bağlılık Öıçekleri Tanımlayııı İstatistikleri}

Tablo 2'de katılımcıların iletişim ve örgütsel bağlllık ölçeklerine ilişkin değerlendirmeleri sonucunda, ölçeklerin ve alt boyutlarının tanımlayıcı istatistikleri yer almaktadır.

Tablo 2. İletişim ve Örgütsel Bağlılık Ölçekleri ve Alt Boyutları Tanımlayıcı İstatistikleri

\begin{tabular}{|l|r|r|r|r|r|}
\hline & Sayı & Min. & Max. & Ortalama & Std. Sapma \\
\hline Duygusal Bağlılık & 384 & 1,00 & 5,00 & 3,2786 &, 98578 \\
\hline Devam Bağlılığı & 384 & 1,00 & 5,00 & 2,9609 &, 87153 \\
\hline Normatif Bağlılık & 384 & 1,00 & 5,00 & 2,8875 &, 98958 \\
\hline Örgütsel Bağlılık-Toplam & 384 & 1,00 & 4,71 & 3,0515 &, 73293 \\
\hline Kişisel başarı duygusu yaratan iletişim & 384 & 1,00 & 5,00 & 3,3380 &, 93088 \\
\hline İletişimin işini tatmin edici bulma yönü & 384 & 1,00 & 5,00 & 3,5737 & 1,03305 \\
\hline Açık iletişim ve iş güvenliği & 384 & 1,00 & 5,00 & 3,5734 &, 94674 \\
Üstlerin açık olmayan davranışları ve & 384 & 1,00 & 5,00 & 3,1266 & 1,07199 \\
denetim algisı & & & & & \\
\hline İletişimin gelişme firsatlarına katkısı & 384 & 1,00 & 5,00 & 3,2281 & 1,28166 \\
\hline İşyeri ilişkilerindeki belirsizlik & 384 & 1,00 & 5,00 & 3,6523 & 1,01485 \\
\hline İletişim-Toplam & 384 & 1,00 & 5,00 & 3,4068 &, 75957 \\
\hline
\end{tabular}

Tablo 2'deki sonuçlara göre, iletişim orta derecede "iyi” olarak değerlendirilmektedir. Katılımcıların örgütsel bağlllık seviyeleri ise orta derecenin altında gerçekleşmektedir.

\section{İletişim ve Örgütsel Bağlılık Ölçekleri İlişsi Analizleri}

Araştırmada iletişim ile örgütsel bağlllık arasındaki ilişkiyi ortaya koymak amacıyla değişkenler arasında Pearson korelasyon analizi yapılmış ve sonuçlara Tablo 3'de yer verilmiştir.

Tablo 3. Korelasyon Analizi

\begin{tabular}{|c|c|c|c|c|c|c|c|c|}
\hline & & $\begin{array}{c}\text { Kişisel } \\
\text { başarı } \\
\text { duygusu } \\
\text { yaratan } \\
\text { iletişim }\end{array}$ & $\begin{array}{c}\text { İletişimin } \\
\text { işini tatmin } \\
\text { edici bulma } \\
\text { yönü }\end{array}$ & $\begin{array}{l}\text { Açık } \\
\text { iletişim ve } \\
\text { iş } \\
\text { güvenliği }\end{array}$ & $\begin{array}{c}\text { Üstlerin açık } \\
\text { olmayan } \\
\text { davranışları ve } \\
\text { denetim algısı }\end{array}$ & $\begin{array}{l}\text { İletişimin } \\
\text { gelişme } \\
\text { firsatlarına } \\
\text { katkıs1 }\end{array}$ & $\begin{array}{c}\text { İşyeri } \\
\text { ilişkilerindeki } \\
\text { belirsizlik }\end{array}$ & $\begin{array}{l}\text { Iletişim } \\
\text { Toplam }\end{array}$ \\
\hline \multirow{2}{*}{$\begin{array}{l}\text { Duygusal } \\
\text { Bağlilık }\end{array}$} & Pearson &, $818^{* * *}$ & ,669** &, $587^{* *}$ &, $690^{* * *}$ & ,016 &, $675^{* *}$ &, $796^{* *}$ \\
\hline & Sig. $(p)$ & ,000 & ,000 & ,000 & ,000 & ,760 & ,000 & ,000 \\
\hline \multirow{2}{*}{$\begin{array}{l}\text { Devam } \\
\text { Bağlılığ1 }\end{array}$} & Pearson &, $168^{* *}$ & ,102* &, $139^{* *}$ & ,126* &, $298^{* *}$ &, $175^{\text {*** }}$ &, $229^{* * *}$ \\
\hline & Sig. $(p)$ & ,001 & ,045 & ,006 & ,013 & ,000 & ,001 & ,000 \\
\hline \multirow{2}{*}{$\begin{array}{l}\text { Normatif } \\
\text { Bağlılık }\end{array}$} & Pearson &, $\mathbf{5 8 9}^{* *}$ &, $\mathbf{4 9 3}^{* *}$ &, $461^{* * *}$ &, $575^{* *}$ & ,098 &, $547^{* *}$ &, $627^{* * *}$ \\
\hline & Sig. $(p)$ & ,000 & ,000 & ,000 & ,000 & ,054 & ,000 & ,000 \\
\hline Örgütsel & Pearson &, $693^{* *}$ &, $556^{* * *}$ &, $\mathbf{5 2 0} * *$ &, $609^{* *}$ & ,171 ${ }^{* *}$ &, $611^{* *}$ &, $7^{2} 3^{* *}$ \\
\hline $\begin{array}{l}\text { Bağll1lk } \\
\text { Toplam }\end{array}$ & Sig. $(p)$ & ,000 & ,000 & ,000 & ,000 & ,001 & ,000 & ,000 \\
\hline
\end{tabular}

Tablo 3'de yer alan sonuçlara göre, "kişisel başarı duygusunu yaratan iletişim" alt boyutu ile duygusal bağl11ı ( $\mathrm{p}=.000<0.05$; Pearson= .818), devam bağl1lı̆ $1(\mathrm{p}=.001<0.05$; Pearson= .168$)$, normatif bağll11k $(\mathrm{p}=.000<0.05$; Pearson= .589) ve toplam örgütsel bağl1lı $(\mathrm{p}=.000<0.05$; Pearson= .693) arasında istatistiksel olarak anlamlı pozitif ilişki bulunmaktadır. 
İletişim ölçeğinin “iletişimin işini tatmin edici bulma yönü” alt boyutu ile duygusal bağlilık $(p=.000<0.05$; Pearson= .669), devam bağl1lı̆g $(p=.045<0.05$; Pearson= .102), normatif bağl1l1k $(p=.000<0.05$; Pearson $=.493)$ ve toplam örgütsel bağl1lık $(p=.000<0.05$; Pearson $=.556)$ arasında istatistiksel olarak anlamlı pozitif ilişki bulunmaktadır.

İletişim ölçeğinin “açık iletişim ve iş güvenliği” alt boyutu ile duygusal bağlılık $(\mathrm{p}=.000<0.05$; Pearson= .587), devam bağlılığ $(\mathrm{p}=.006<0.05$; Pearson= .139), normatif bağl1lık $(\mathrm{p}=.000<0.05$; Pearson $=.461)$ ve toplam örgütsel bağl111k $(\mathrm{p}=.000<0.05$; Pearson= .520$)$ arasında istatistiksel olarak anlamlı pozitif ilişki bulunmaktadır.

İletişim ölçeğinin "üstlerin açık olmayan davranışları ve denetim algısı" alt boyutu ile duygusal bağlılık $(\mathrm{p}=.000<0.05$; Pearson $=.690)$, devam bağl1lı̆g $(\mathrm{p}=.013<0.05$; Pearson $=.126)$, normatif bağl1lık $(p=.000<0.05$; Pearson= .575) ve toplam örgütsel bağl1lık $(p=.000<0.05$; Pearson= .609) arasında istatistiksel olarak anlamlı pozitif ilişki bulunmaktadır.

İletişim ölçeğinin "iletişimin gelişme firsatlarına katkısı" alt boyutu ile devam bağl1lı̆g 1 ( $=.000<0.05$; Pearson $=.298)$, ve toplam örgütsel bağl1lık $(\mathrm{p}=.001<0.05$; Pearson= .171) arasında istatistiksel olarak anlamlı pozitif ilişki bulunmaktadır. "İletişimin gelişme firsatlarına katkısı" alt boyutu ile duygusal bağl1lık ( $\mathrm{p}=.016>0.05)$ ve normatif bağl1lık $(\mathrm{p}=.054>0.05)$ arasında ise istatistiksel olarak anlamlı bir ilişki bulunmamaktadır.

İletişim ölçeğinin "işyeri ilişkilerindeki belirsizlik" alt boyutu ile duygusal bağlılık $(p=.000<0.05$; Pearson= .675), devam bağl11. $\breve{g} 1(p=.001<0.05$; Pearson= .175), normatif bağl1lık $(\mathrm{p}=.000<0.05$; Pearson $=.547)$ ve toplam örgütsel bağl1lık $(\mathrm{p}=.000<0.05$; Pearson= .611) arasında istatistiksel olarak anlamlı pozitif ilişki bulunmaktadır.

İletişim ölçeğinin toplamı ile duygusal bağlılık $(\mathrm{p}=.000<0.05$; Pearson= .796), devam bağl1lığ1 $(p=.000<0.05$; Pearson $=.229)$, normatif bağl1lık $(p=.000<0.05$; Pearson $=.627)$ ve toplam örgütsel bağlılık $(\mathrm{p}=.000<0.05$; Pearson= .723) arasında istatistiksel olarak anlamlı pozitif ilişki bulunmaktadır. Ayrıca iletişimin örgütsel bağlılık ve alt boyutları üzerindeki etkilerini analiz etmek için basit doğrusal regresyon analizi yapılmıştır. Sonuçlar Tablo 4'de yer almaktadır.

Tablo 4. Regresyon Analizi

\begin{tabular}{clcccc}
\hline $\begin{array}{c}\text { Bağımlı } \\
\text { Değişken }\end{array}$ & \multicolumn{1}{c}{ Bağımsız Değişken } & $\boldsymbol{\beta}$ & $\mathbf{t}$ & $\mathbf{R}^{\mathbf{2}}$ & $\mathbf{p}$ \\
\hline İletişim-toplam & Duygusal Bağlılık & .796 & 25.738 & .634 & $\mathbf{. 0 0 0}$ \\
İletişim-toplam & Devam Bağl1lı̆̆ & -.554 & -11.605 & .648 & $\mathbf{. 0 0 0}^{*}$ \\
İletişim-toplam & Normatif Bağl1lık & -.510 & -6.762 & .648 & $\mathbf{. 0 0 0}^{*}$ \\
İletişim-toplam & Örgütsel Bağl1lık-Toplam & .723 & 20.462 & .523 & $\mathbf{. 0 0 0}^{*}$ \\
\hline
\end{tabular}


Tablo 4'de yer alan sonuçlara göre, iletişimin duygusal bağlılık $(p=.000<0.05 ; \beta=.796)$ ve toplam örgütsel bağl1lık ( $\mathrm{p}=.000<0.05 ; \beta=.723)$ üzerinde istatistiksel olarak anlamlı ve pozitif bir etkisi bulunmaktadır. İletişimin devam bağ l11ı̆̆ $(\mathrm{p}=.000<0.05 ; \beta=-.554)$ ve normatif bağl1lık $(\mathrm{p}=.000<0.05$; $\beta=-.510$ ) üzerinde ise yine istatistiksel olarak anlamlı ancak negatif etkisi olduğu görülmektedir.

\section{SONUÇ}

Bu çalışmada algılanan iletişim şeklinin örgütsel bağlılığa etkisi araştırma konusu olmuştur. Araştırma Türkiye'deki bankacılık sektörü üzerinde yapılmış ve Türkiye'deki bankacılık sektöründe örgüt içi iletişimin hangi seviyede sağlıklı olarak algılandığını bulmak; Türkiye'deki bankacılık sektöründe örgütsel bağlılık seviyesini tespit etmek ve; Türkiye'deki bankacılık sektöründe algılanan iletişim şeklinin örgütsel bağlılığa etkisini araştırmak; çalışma kapsamında ele alınan konulardandır.

Araştırmada anket yöntemi kullanılmıştır ve toplam 384 banka çalışanı bu çalışmaya katılmıştır. Araştırmanın analizinde ilk önce betimsel istatistiklere yer verilmiş olup mean-median analizleri yardımıyla Türk bankacılık sektöründeki örgüt içi iletişimin sağlılılı̆̆ı ve örgütsel bağlılık seviyeleri belirlenmiştir. Bunu takiben korelasyon analizleri ve regresyon analizleri yapılarak algılanan iletişim şekli ve örgütsel bağlılık arasındaki ilişki ve etkileşimler tespit edilmiştir.

Sonuçlar göstermiştir ki Türk bankacılık sektöründe iletişim orta derecede "iyi” sağlıklı olarak değerlendirilmektedir. Bu durum çalışanlar tarafından belirtilen iletişim derecesinin yeterince sağlıklı olmadığını ve bu anlamda gelişime açık olduğunu göstermektedir. Bu anlamda inceleme altındaki bankacılık sektöründe var olan iletişimin toksik iletişime açık bir seviyede olduğu tespit edilmiştir. Toksik iletişimin oluşması örgütler için ciddi sorunlara yol açabilmektedir. Bu sorunların en başında çalışanların motivasyon düşüklüğü gelmektedir. Temelde örgütün kendisi için ne düşündüğünü anlamakta güçlük çeken çalışan işine karşı motive olamamakta, işinden duyduğu tatmin düşmekte ve örgütsel bağlılığı azalmaktadır.

Benzer şekilde örgütün hedeflerini ve amaçlarını tam olarak anlayamayan çalışanlar da örgüt performansına yeteri kadar katkıda bulunamamaktadır. Tüm bu durumlar göz önünde bulundurulduğunda bu araştırma kapsamında bulunan algılanan iletişim seviyesinin geliştirilmesi gerektiği söylenebilecektir. Bunun için yapılması gereken girişimlerin başında sağlıklı iletişim kanallarının kurulması ve kullanılması ve örgüt içi iletişimin açık ve hızlı bir şekilde gerçekleşmesi için çaba sarf edilmesi gelmektedir. Yine, iletişim konusunda yaşanan güçlüklerin ve olumsuz yönlerin belirlenebilmesi için çalışan görüşlerinin belirli periyodlarda alınması gerekmektedir.

Bu araştırmanın diğer sonuçları göstermiştir ki Türkiye' deki bankacılık sektöründe örgütsel bağlılık seviyesi orta derecenin altında gerçekleşmektedir. Örgütsel bağlılık firmalar için hayati bir konudur. 
Çünkü firmalar çalışanlarının kendilerine uzun süre hizmet etmelerine bekleyerek onlara eğitimler aracılığıyla oldukça fazla yatırım yapmaktadır. Ancak örgütsel bağlılığı olmayan çalışanlar ilk firsatta rakip firmalara geçmeye meyillidirler. $\mathrm{Bu}$ anlamda firmalar sadece yetişmiş çalışanlarını kaybetmemekte, aynı zamanda rakip firmalara yetişmiş çalışan sağlayarak onlara ciddi maliyet avantajı sağlamaktadır. Bu nedenle bu araştırma sonuçlarına göre bankacılık sektöründe örgütsel bağglı̆ğın geliştirilmesi gerekmektedir denilebilecektir. Bunun için yapılması gerekenlerin başında iş tatminini arttırmak için çalışanları maddi ve manevi olarak desteklemek, örgüt içinde yükselmenin önünü açmak ve sağlıklı iletişim stratejileri geliştirmek gelmektedir.

$\mathrm{Bu}$ araştırma kapsamında gerçekleştirilen korelasyon analizleri iletişim ve örgütsel bağlılık arasında pozitif yönlü bir ilişki olduğunu işaret etmiş olsa da regresyon analiz sonucunda bankacılık sektöründeki örgüt içi iletişimin devam bağlılığı ve normatif bağlılığı negatif yönlü etkilediği tespit edilmiştir. Bu durum sektörde algılanan örgüt içi iletişimin sağlıksız iletişim olduğunu ve literatürde belirtildiği üzere sağlıklı iletişimin örgütsel bağlılığı pozitif yönlü etkilemesi gerekirken (Bektaş \& Erdem, 2015; Certo \& Certo, 2006; Eğinli \& Bitirim, 2008) var olan iletişimin örgütsel bağlılık üzerinde negatif bir etkisinin olduğunu ortaya koymaktadır.

Bu sonuçlar bir kez daha göstermiştir ki iletişim örgütler için oldukça önemli bir konudur ve yeterli olmayan bir örgüt içi iletişimin var olması örgütsel bağl1lık gibi bir diğer hayati konuyu negatif yönde etkilemektedir. Literatürde belirtildiği üzere sağlıksız iletişimin azalması için yöneticiler tarafından gerçekleştirilen informel ziyaretlerde kullanılan dile özen gösterilmesi, şakaların yanlış algılanmasının önüne geçmek amacıyla dikkatli kullanılması, açık ve net bir iletişim kurularak şirket içi laf taşıyıcılarının önüne geçilmesi ve böylece dedikodunun önlenmesi gerekmektedir. 


\section{KAYNAKÇA}

Aldehayyat, J. (2011). Organisational Characteristics and the Practice of Strategic Planning in Jordanian Hotels, International Journal of Hospitality Management, 30, 192-199.

Allport, G.W. \& Postman, L. (1947). The psychology of rumor, Henry Holt \& Co., New York.

Appelbaum, S.H., Iaconi, G.D. \& Matousek, A. (2007). Positive and Negative Deviant Workplace Behaviors: Causes, Impacts, and Solutions, Corporate Governance, 7(5), 586-598.

Bektaş, M. \& Erdem, R. (2015). Örgütlerde İnformal İletişim Süreci: Kavramsal Bir Çerçeve, AKÜ İIBF Dergisi, 17(1), 125-139.

Bektaş, M. \& Erkal, P. (2015) Toxicity Behaviors in Organizations: Study of Reliability and Validity of Toxic Emotional Experiences Scale, Research Journal of Business and Management, 2(4), 519-529.

Bektaşoğlu, A. \& Şengün, H. (2020). Sağl1k Sektöründe Örgütsel İletişimin Örgütsel Bağlılık Üzerine Etkilerini Belirlemeye Yönelik Bir Araştırma, Aydın Sağlık Dergisi, 6(2), 155-182.

Benkhoff, B. (1997). Disentangling organizational commitment: the dangers of the OCQ for research policy, Personnel Review, 26, 114-131.

Bovee, C.L. \& Thill, J.V. (2010.). Business Communication Today (10th Ed.), Pearson Education, New Jersey.

Certo, C.S. \& Certo, S.T. (2006). Modern Management, Pearson Education Ltd, New York.

Cheney, G. \& Christensen, L. (2001). Organisational identity linkages between internal and external communication, In F.M. Jablin \& L.L. Putnam (Eds.). The New Handbook of Organisational Communication, Sage, Thousand Oaks, pp. 231-269.

Demirtaş, M. (2010). Örgütsel İletişimin Verimlilik ve Etkinliğinde Yararlanılan İletişim Araçları ve Halkla İlişskiler Filmleri Örneği, Marmara Üniversitesi İ̈BF Dergisi. XXVIII.I, 411-444.

Eğinli, A.T. \& Bitirim, S. (2008). Kurumsal Başarının Önündeki Engel: Zehirli (Toksik) İletişim, Selçuk İletişim, 5(3), 124-140.

Gaertner, S. (1999). Structural determinants of job satisfaction and organizational commitment in turnover models, Human Resource Management Review, 9(4), 479-493.

Geçikli, F., Serçeoğlu, N. \& Üst, Ç. (2011). Örgüt İçi İletişim ve İletişim Tatmini Konaklama İşletmelerinde Bir Uygulama, İletişim Kuram ve Araştırma Dergisi, (33), 163-184. 
Guerin, B. \& Yoshihiko, M. (2006). Analyzing Rumors, Gossip and Urban Legends Through Their Conversational Properties, The Psychological Record, 56, 23-34.

Gül, H. (2002). Örgütsel bağl1lık yaklaşımlarının mukayesesi ve değerlendirmesi, Ege Academic Review, 2(1), 37-56.

Gümüş, M. \& Öksüz, B. (2009). Çalışanların Kurumsal İtibar Sürecine Katılımlarında İçsel İletişimin Rolü, Journal of Yasar University, 4(16), 2637-2660.

Güney, S. (2001). Yönetim ve Organizasyon, Nobel Yayın Dağıtım, Ankara.

Halis, M. (2000). Örgütsel İletişim ve İletişim Tatminine İlişkin Bir Araştırma, İktisadi ve İdari Bilimler Dergisi, 14(1), 217-230.

Kalla, H.K. (2005). Integrated Internal Communications: A Multidisciplinary Perspective, Corporate Communications: An International Journal, 10(4), 302-314.

Koçel, T. (2018). İşletme Yöneticiliği (18. Bask1), Beta Yayınları, İstanbul.

Kotler, P. \& Keller, K.L. (2006). Marketing Management (12th Ed.), Prentice Hall, New Jersey.

Metcalfe, B. \& Dick, G. (2001). Exploring organisational commitment in the police: implications for human resource strategy, Policing: An International Journal of Police Strategies and Management, 24(3), 399-419.

Meyer, J.P. \& Allen, N.J. (1991). A three-component conceptualization of organizational commitment, Human Resources Management Review, 1(1), 61-89.

Meyer, J.P. \& Allen, N.J. (1997). Commitment in the workplace: Theory, research and application, Sage Publications, Thousand Oaks.

Miller, K. (2003). Values, attitudes and job satisfaction, In S.P. Robbins, A. Odendaal, G. Roodt (Eds.). Organizational Behavior: Global and Southern African Perspective, Pearson Education South Africa, Cape Town.

Moutoux, D. \& Porte, M. (1979). Small Talk in Industry, The Journal of Business Communication, 17(2), 1-11.

Oliver, S. (2007). Public Relations Strategy (2nd Ed.), Kogan Page, London.

Porter, L.W., Steer, R.M., Mowday, R.T. \& Boulian, P.V. (1974). Organizational Commitment, job satisfaction and turnover among psyciatric technicians, Journal of Applied Psychology, 59, 603-609.

Randall, D.M. (1990). The consequences of organizational commitment: Methodological investigation, Journal of Organizational Behavior, 11(5), 361-378.

Reichers, A.E. (1985). A review and reconceptualization of organizational commitment, Academy of Management Review, 10, 465-476. 
Rosnow, R.L. (1991). Inside Rumor: A Personal Journal, American Psychologist, 484496.

Solmaz, B. (2004). Söylentilerin Kurumsal İletişim Açısından Değerlendirilmesi Ve Bir Uygulama Örneği, Selçuk İletişim, 3(3), 120-127.

Steingrimsdottir, H. (2011). The Relationship between Internal Communication and Job Satisfaction. A Case Study, Copanhagen Bussiness School MCM, 20.

Storey, J. (2007). Human Resource Management: A Critical Text (3rd Ed.), Routledge, London.

Subramaniam, N. \& Mia, L. (2001). The relation between decentralised structure, budgetary participation and organisational commitment: The moderating role of managers' value orientation towards innovation, Accounting, Auditing \& Accountability, 14(1), 12-29.

Tanrıverdi, H., Adıgüzel, O. \& Çiftçi, M. (2010). Sağlık Yöneticilerine Ait İletişim Becerilerinin Çalışan Performansına Etkileri: Kamu Hastanesi Örneği, Süleyman Demirel Üniversitesi Sosyal Bilimler Enstitüsü Dergisi, 1(11), 101-122.

Tourish, D. \& Hargie, O. (2004). Key Issues in Organisational Communication, Routledge, London.

Türkiye Bankalar Birliği (2020). Bankacılık Sisteminde Banka, Çalışan ve Şube Sayıları, Mart 2020, URL: https://www.tbb.org.tr/Content/Upload/istatistikiraporlar/ekler/1295/Banka_Calis an_ve_Sube_Sayilari-Mart_2020.pdf

Ünüvar, Ş. \& Bilge, A. (2009). Örgütsel İletişimin Bir Unsuru Olan Örgüt İçi İletişimin konaklama İşletmelerindeki Etkinliği: Örnek Bir Alan Araştırması, Journal of Azerbaijani Studies, 12(1), 55-72.

Williams, L.J. \& Anderson, S.E. (1991). Job satisfaction and organizational commitment as predictors of organizational citizenship and in-role behaviors, Journal of Management, 17(3), 601-617.

Yousef, D.A. (2003). Validating the Dimensionality of Porter et al.'s Measurement of Organizational Commitment in a Non-Western Culture Setting, International Journal of Human Resource Management, 14(6), 1067-1079.

Zeffane, R. (1994). Patterns of Organizational Commitment and Perceived Management Style: A Comparison of Public and Private Sector Employees, Human Relations, 47. 